\title{
[ Where Is My Homeland?: The Pilgrimage of Marcela Sulak ]
}

\section{David Livingstone}

Palacký University,

Olomouc, Czech Republic

[Abstract] This essay examines the literary output of Marcela Sulak, a Texas-born Czech poet and academic now living and working in Tel Aviv, Israel. There is a focus not only on her recently published memoir, but on her poetry and her translations of two Czech classics (Mácha and Erben) into English. The primary interest of the essay is in exploring her search for identity, not only geographically, but also spiritually. Increased attention is paid to those aspects of her life and work connected with the Czech nation, history, culture and language.

[Keywords] memoir; identity; Czech; translation; poetry 
Marcela Sulak's recently published memoir, Mouth Full of Seeds, begins, in the opening section entitled 'Drawn That Way', with the following captivating lines: "On my birthday my mother writes me: What is it about you that allows you to pick up, with your little daughter, and leave all your former life behind? Your background, your family, nationality, religion, friends, siblings, parents, your roots. And just start a new life in a new country?" (Sulak, Mouth 3). The implied criticism here is somewhat ironic given the fact that her great-grandparents had done something alone the same lines, leaving their homeland behind, around the turn of the twentieth century, to start a completely new life.

Sulak (pronounced as if the Czech háček was still there) is a Tex Czech or a Czech Tex, brought up Catholic as a third/fourth generation Czech American and now a convert to Judaism living and teaching in Israel. She is not only an academic, but also a poet and translator. She is currently head of the Shaindy Rudoff Graduate Program in Creative Writing at Bar-Ilan University in Tel Aviv, Israel. This is one of the few programs focused on writing prose and poetry in English outside English speaking countries. Sulak is also the managing editor of the literary journal Ilanot Review, has a weekly podcast about Israeli literature and is involved in a range of further literary endeavours. She has published three volumes of her own poetry, with her fourth City of Sky Papers out in May 2021 from Black Lawrence Press. She also publishes poetry translations from French, Hebrew and Czech, having published two classics in the last mentioned language: Karel Hynek Mácha's May and Karel Jaromír Erben's Bouquet. She has also written a number of essays and published a fascinating memoir Mouth Full of Seeds. She recently spent a half year in Olomouc teaching literary translation and creative writing at the Department of English and American Studies at Palacký University. During her stay, she was also working on another translation from Czech, this time Vítězslav Nezval's The Jewish Cemetery. I have had the pleasure of sharing an office with her during her stay and would like to look at her Czechness and identity in general as manifested in her memoir, her poetry and the translations from Czech.

Her great-grandparents were from various parts of Wallachia and immigrated to Texas with her grandparents who were still children. They responded to advertisements offering cheap land. They made their living on rice farms in Jackson and Wharton counties in south-east Texas, which was, and still is, heavily populated with ethnic Czechs. Her parents already had a limited knowledge of Czech and Sulak's exposure to the language was through her grandparents speaking it and through learning nursery rhymes. She writes of this in her memoir: "Like many Texas-born, my mother tongue was not my mother's tongue. Or, rather, it was by the time I was born, because my mother, having learned English in School, soon forgot all her Czech except for the rosary and a few phrases. It was patriotic to forget" (Sulak, Mouth 104).

Apart from language, there was a continued interest amongst thelocals in Czech food, with people in the area proud of their Czech recipes and even guarding them with pride and secrecy. Sulak manifested an early interest in writing and poetry in particular, beginning to write in the fifth grade and encouraged to do so by one of her teachers. She completed her undergraduate studies at University of Texas in Austen where she studied English and psychology. This was followed by her MA and MFA at Notre Dame in South Bend, Indiana. 
Sulak decided to deepen her knowledge of the culture and language with a work stay in České Budějovice in 1993-1994, where she taught English and Spanish at one of the secondary schools (gymnasium). While there, she began to study Czech seriously using, among other things, a somewhat ambitious Czech classic of the nineteenth century. She explains the context in an interview dealing with her first translation. "I was given this book, 'Kytice' or 'A Bouquet' by Erben, and I began to read it. My colleagues, friends and students were so excited that I was reading it that they generously helped me out. I spent many days at their houses going over arcane words and trying to figure out what was written. The vocabulary is very difficult, so I found that I was keeping so many notes that it ended up being the basis of the translation" (Vaughan, Erben). As if Erben was not hard enough, her translation of Mácha's classic May also had its origins from her stay in South Bohemia. She speaks of this in yet another interview.

When I first arrived in the Czech Republic, I had just finished university, and I really liked romantic poetry. Students and friends asked me, 'You've never read Mácha?' And I looked through and realized that he hadn't been translated into English, or he had been but quite a long time ago, and the editions were no longer available. So I decided to read it in Czech. Now, at the time, I had been there for six months and reading it in Czech meant that I was basically translating it as I read it. So, once I got finished I thought, 'Well, why not continue?' (Vaughan, Mácha)

Sulak continued with her studies with a time spent studying philosophy in the German language in Tübingen and with another MA at Villanova University in Pennsylvania. This was followed by yet another formative experience abroad in Venezuela where she worked over the years 1998-2000 on a project about the Sephardic Jews who ended up there and where, surprisingly, she first visited a synagogue. She writes of the impact of this and her earlier and later stays in foreign countries in her memoir: "As my body moved over different lands, Venezuela, Germany, Czech Republic, and now Israel, and different languages flowed through my mouth, I became a literary translator and sometimes simultaneous interpreter" (Sulak, Mouth 107). She finally culminated her studies with a return to Austin where she completed her $\mathrm{PhD}$ and wrote her dissertation on a topic particularly relevant to her ongoing creative and academic pursuits: Ligatures of Time and Space: $1920 \mathrm{~s}$ New York as a Construction Site for Modernist “American” Narrative Poetry.

Sulak not only left her physical home far behind, but also gradually abandoned her Catholic faith and even eventually converted to Judaism. The faith of her forefathers and foremothers was seemingly very much tied up in her own mind and body with the Czech Lands and with her own growing feminist consciousness. "Maybe if Catholic church altars featured statues of Mary with a baby and a book, instead of a crucified, bloody body of a man, I'd have stayed Catholic and become a Catholic Mother in our ancestral homeland, Moravia" (Sulak, Mouth 3).

After obtaining her doctorate, Sulak accepted a position at American University in Washington DC, where she taught literary translation and world literature, among other subjects, for five years. While in the nation's capital, she gave birth to her daughter 
Amalia who is often mentioned in her memoirs. As a single mother, Sulak has been subject to scrutiny and disapproval from not only family members and in-laws, but also from the various cultures she has lived in and visited. She mentions the stigma in connection with her own upbringing in her memoir: "Growing up in rural Texas, I had known about single mothers the same way I knew about snow and maple leaves, skyscrapers and subways-I'd read about them in books" (Sulak, Mouth 29).

Another recurring subject in her books is fruit and vegetables, perhaps partially due to her vegetarianism, but also possibly connected with her interest in place, her fascination with the particular flora of the place she is living in at a particular time. While Mouth Full of Seeds (the name itself is food for thought) contains sections entitled 'Potatoes' and 'The History of the Pea', her poetry collections are rife with references: 'Avocado', 'The History of Brussels Sprouts', 'Plums', 'Cabbage, a Love Song', 'The History of the Radish', 'Yam', The History of the Watermelon', 'The History of the Papaya', 'Chocolate', 'Raspberry', 'Pomegranate', as well as a number of poems dealing with cooking and gardening. The poem 'Plums', from her first collection Immigrant, seems to me a particularly Wallachian poem (a region famed for its slivovitz moonshine made from plums), where Sulak seems to be reconnecting with her ancestral homeland and its troubled history.

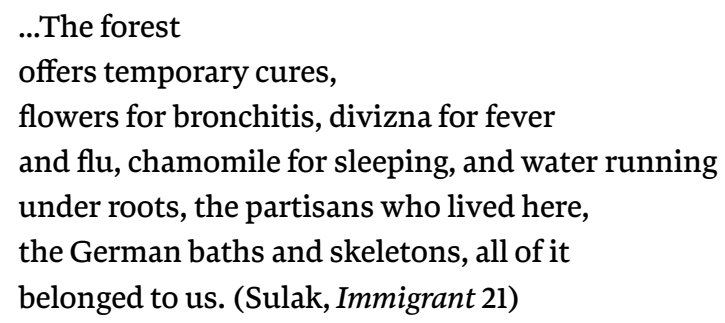

The poem once again displays Sulak's typical attention to the herbs and flora around her as well as her obvious passion to learn about the local history and culture.

This is also very much in evidence in her preface to Erben's Bouquet where she depicts and celebrates not only the, at least at that time, groundedness of many Czechs with their passion for herbs and wild fruit and vegetables, but her own ability to absorb and record in verse her personal, sensual, tactile and taste (in both senses of the word) experiences.

...three years after the Velvet Revolution, living and working in the country, I was struck with what felt to me to be a respect for the imagination and for the natural world that we associate with childhood. In fact, I could go into the fields or woods on any given day in any given season with any school child or adult and come home with an armload of delicacies we had gathered on our way: mushrooms, cherries, wild strawberries, blueberries, elderberry flowers (for fritters, syrup, or wine), young nettle for salad or tea, chamomile, St. John's Wort, Mullein. I was introduced to all the sacred trees, the birch groves, the historical lindens, and others. (Sulak, Bouquet 10-11) 
The memoir also touches on her current home in Tel Aviv, Israel with all the cultural differences involved, language struggles at times and once again her life as a single mom. "When people ask me how I like Israel, if I plan to stay, I say that I am over the angry phase. Over all that bursting into tears when strangers yell at me for no reason in the street" (Sulak, Mouth). Sulak has been teaching American literature, literary translation and creative writing for a number of years now at Bar-Ilan University. Thanks to her efforts, a number of her students have gone on to publish their work, with a great deal of their success due to her support and insight. She is also fully involved in the literary scene in Israel with her translations from Hebrew, podcast on Israeli literature and the editorial work for her journal, amongst other things.

Sulak arrived with her daughter in Olomouc in December 2020 and stayed through the summer of 2021. Apart from teaching online at her home institution, she very generously agreed to teach two classes at our department: literary translation and creative writing. Although this period of lock-down has not been the ideal time to enjoy what the city and country have to offer, much pleasure and joy was still to be had. Sharing an office, we have had the pleasure of drinking beer and slivovitz in the office, had small office parties, commented on the ongoing shenanigans of a local woodpecker pecking holes in the facade outside our window, ate take-away meals together, and even listened to one another teach on-line. I have found myself amused and intrigued at times by her attempts to draw out my painfully reticent and shy students, a stark contrast to the frequently aggressive, in-your-face, approach of her Israeli students. Despite the differences in the students, she displays a remarkable enthusiasm about everything and a genuine generosity of spirit and willingness to share her work.

Her most recent collection, City of Skypapers (the title indebted to her daughter) contains a poem about animals for a change. The poem 'Golden Jackals' describes these wild members of the canine family who are quite common where she lives in Tel Aviv. Her observations, concerned with the mating rituals of jackals, draw parallels not only with human behaviour in general, but with the locals and with her own pilgrimage in search of a homeland.

Father jackals help the mother

raise the young. When they are old enough, they are

driven from home, but like Tel Avivis, they tend to stay

in the neighborhood. Not me. I was born a stray.

Something tipped a painted glass sky over the earth,

and I live here, in the bubble between. (Sulak, City 40)

Being a stray requires a great deal of bravery, but also means you might get invited to join someone else's pack until it's time to move on again. Sulak has done just that, sharing her talents, writing and teaching with people all around the globe. Her "bubble between" could serve as an apt description of her constantly shifting and searching quest for a homeland, a pilgrimage which she thankfully provides us access to through her writing, translations and teaching. 


\section{[Bibliography]}

Sulak, Marcela. City of Skypapers. Brooklyn: Black Lawrence Press, 2021.

Sulak, Marcela. Immigrant. Brooklyn: Black Lawrence Press, 2010.

Sulak, Marcela. Karel Hynek Macha's May. Prague: Twisted Spoon Press, 2014.

Sulak, Marcela. Karel Jaromir Erben's Bouquet of Czech Folktales. Prague: Twisted Spoon Press, 2012.

Sulak, Marcela. Mouth Full of Seeds. Brooklyn: Black Lawrence Press, 2020.

Vaughan, David. "Karel Hynek Mácha: the Poet of Lovers.” Radio Prague International. Web. 14 November 2010. https://english.radio.cz/karel-hynek-macha-poet-lovers-8568498

Vaughan, David. “Karel Jaromír Erben: a Not Quite So Frim Fairytale.” Radio Prague International. Web. 27 July 2013. https://english.radio.cz/karel-jaromir-erben-a-not-quite-so-grim-fairytale-8544032

\section{[Address]}

Department of English and American Studies

Faculty of Arts

Palacký University

Křžžkovského 10

77900 Olomouc

Czech Republic

livingstone@seznam.cz

David Livingstone has taught English Literature at Palacký University, Olomouc Czech Republic for the last twenty-five years. His academic interests include Shakespeare, Children's Literature and American Folk Music. He recently published a book In Our Own Image: Fictional Representations of William Shakespeare with Palacký University Press. 